\title{
A Structural Guide to Proteins of the NF-кB Signaling Module
}

\author{
Tom Huxford ${ }^{1}$ and Gourisankar Ghosh ${ }^{2}$ \\ ${ }^{1}$ Department of Chemistry and Biochemistry, San Diego State University, 5500 Campanile Drive, San Diego, \\ California 92182-1030 \\ ${ }^{2}$ Department of Chemistry and Biochemistry, University of California, San Diego, 9500 Gilman Drive, La Jolla, \\ California 92093-0375 \\ Correspondence: gghosh@ucsd.edu
}

The prosurvival transcription factor NF- $\mathrm{kB}$ specifically binds promoter DNA to activate target gene expression. NF- $\kappa B$ is regulated through interactions with $1 \kappa B$ inhibitor proteins. Active proteolysis of these IкB proteins is, in turn, under the control of the IкB kinase complex (IKK). Together, these three molecules form the NF-kB signaling module. Studies aimed at characterizing the molecular mechanisms of $\mathrm{NF}-\kappa \mathrm{B}, \mathrm{I \kappa B}$, and IKK in terms of their three-dimensional structures have lead to a greater understanding of this vital transcription factor system.

$\mathrm{N}_{\mathrm{re} e \mathrm{sen}}^{\mathrm{F}}$ $\mathrm{F}-\kappa \mathrm{B}$ is a master transcription factor that responds to diverse cell stimuli by activating the expression of stress response genes. Multiple signals, including cytokines, growth factors, engagement of the T-cell receptor, and bacterial and viral products, induce NF-кB transcriptional activity (Hayden and Ghosh 2008). A point of convergence for the myriad of NF- $\kappa$ B inducing signals is the IкB kinase complex (IKK). Active IKK in turn controls transcription factor NF- $\kappa \mathrm{B}$ by regulating proteolysis of the ІкB inhibitor protein (Fig. 1). This nexus of three factors, IKK, IKB, and NF- $\kappa$ B, forms the NF- $\kappa$ B signaling module-a molecular relay switch mechanism that is conserved across diverse species (Ghosh et al. 1998; Hoffmann et al. 2006). In this article, we introduce the human NF- $\kappa$ B, IкB, and IKK proteins, and discuss how they function from the perspective of their three-dimensional structures.

$N F-\kappa B$

Introduction to $\mathrm{NF}-\kappa \mathrm{B}$

$\mathrm{NF}-\kappa \mathrm{B}$ was discovered in the laboratory of David Baltimore as a nuclear activity with binding specificity toward a ten-base-pair DNA sequence $5^{\prime}$-GGGACTTTCC-3' present within the enhancer of the immunoglobin $\kappa$ light chain gene in mature antibody-producing $B$ cells (Sen and Baltimore 1986). The biochemically purified activity was found to be composed of 50 and 65 kilodalton ( $\mathrm{kDa}$ ) subunits. Cloning of the p50 subunit revealed significant aminoacid sequence homology between its aminoterminal 300 amino acids and the oncogene

Editors: Louis M. Staudt and Michael Karin

Additional Perspectives on NF-кB available at www.cshperspectives.org

Copyright (C) 2009 Cold Spring Harbor Laboratory Press; all rights reserved; doi: 10.1101/cshperspect.a000075

Cite this article as Cold Spring Harb Perspect Biol 2009;1:a000075 


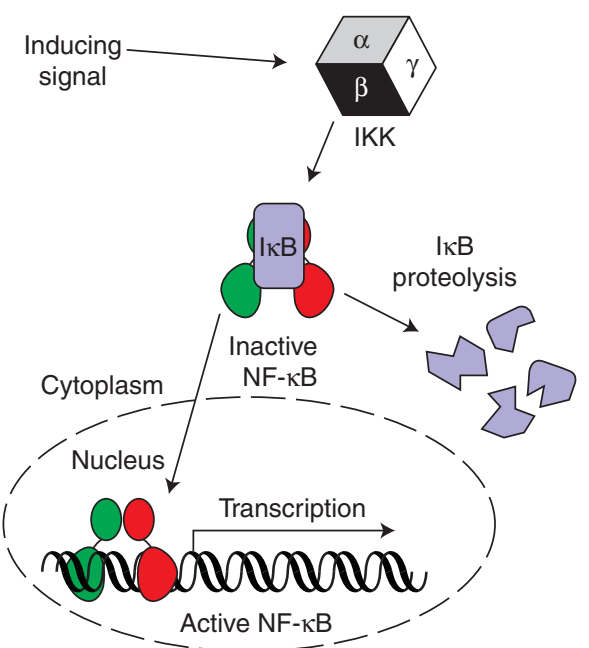

Figure 1. The NF- $\kappa B$ signaling module. NF- $\kappa B$ exists in the cytoplasm of resting cells by virtue of its noncovalent association with an I $\mathrm{I} B$ inhibitor protein. The IкB kinase (IKK) responds to diverse stimuli by catalyzing the phosphorylation-dependent $26 \mathrm{~S}$ proteasome-mediated degradation of complexassociated IкB. Active NF- $\kappa \mathrm{B}$ accumulates in the nucleus where it binds with DNA sequence specificity in the promoter regions of target genes and activates their transcription.

from the reticuloendotheliosis virus of turkeys and shared by v-Rel and its cellular protooncogene c-Rel. This portion of conserved amino acid sequence was termed the Rel homology region (RHR). As is discussed later, the mRNA responsible for producing the p50 subunit was found to encode a longer precursor protein of $105 \mathrm{kDa}$ in size that possesses the entire p50 amino-acid sequence at its amino-terminal end and its own inhibitor within its carboxy-terminal region. Once the cDNA encoding the p65 subunit (also known as RelA) was sequenced, it was also found to contain an amino-terminal RHR. Two additional NF- $\mathrm{BB}$ family subunits, RelB and p52 (the processed product of a longer $100-\mathrm{kDa}$ precursor), were also discovered to harbor the conserved RHR within their aminoterminal regions. These five polypeptides, p50, p65/RelA, c-Rel, p52, and RelB, constitute the entire family of NF- $\mathrm{B}$ subunits encoded by the human genome (Fig. 2A).

\section{Rel Homology Region Structure}

The first glimpse at the structure of the RHR was afforded by the successful determination of two $\mathrm{x}$-ray crystal structures of the NF- $\mathrm{BB}$ р50:p50 homodimer in complex with related $\kappa \mathrm{B}$ DNA (Ghosh et al. 1995; Müller et al. 1995). The structures uncovered a symmetrical protein: DNA complex structure reminiscent of a butterfly with double-stranded DNA comprising the "body" and two-protein subunit "wings" (Fig. 2B,C). These structures revealed a completely novel DNA binding motif in which one entire 300 amino acid RHR from each p50 subunit in the dimer are involved in contacting one whole turn along the major groove of double-stranded DNA (Baltimore and Beg 1995; Müller et al. 1996).

As revealed by the NF- $\kappa$ B p50:DNA complex structures, the RHR consists of two folded domains. The amino-terminal domain (or Rel-N) is approximately $160-210$ amino acids in length and exhibits a variant of the immunoglobulin fold. The carboxy-terminal dimerization domain (referred to as Rel-C) spans roughly 100 amino acids and also adopts an immunoglobulin-like fold. The five RHRcontaining NF- $\kappa \mathrm{B}$ subunits assemble to form various homo- and heterodimer combinations to form active NF- $\kappa$ B transcription factors. The two domains are joined by a short flexible linker approximately 10 amino acids in length. A carboxy-terminal flexible region in which is embedded the nuclear localization signal terminates the conserved RHR portion of the NF- $\kappa \mathrm{B}$ subunits. Besides dimerization, this RHR is responsible for sequence-specific DNA binding, nuclear localization, and interaction with IкB proteins.

Outside of the conserved RHR, three NF-кB subunits, p65/RelA, c-Rel, and RelB, contain a transcription activation domain (TAD) at their extreme carboxy-terminal ends. This region, which is poorly understood in protein structural terms, is responsible for the increase in target gene expression that results from induction of NF- $\kappa \mathrm{B}$ and, consequently, NF- $\kappa \mathrm{B}$ dimers that possess at least one of these subunits function as activators of transcription. 
A

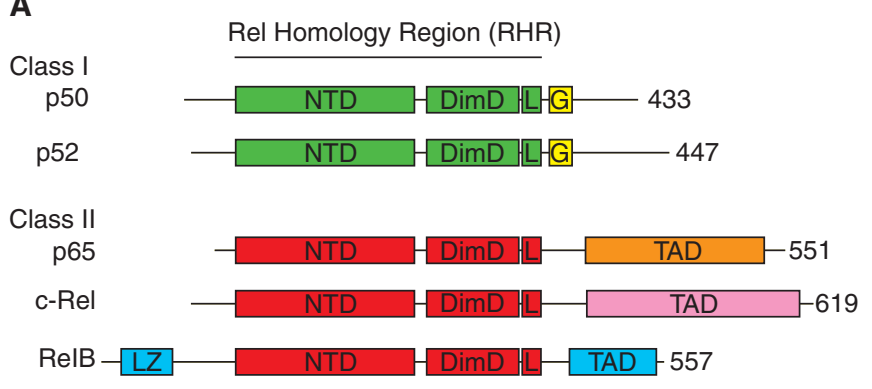

C

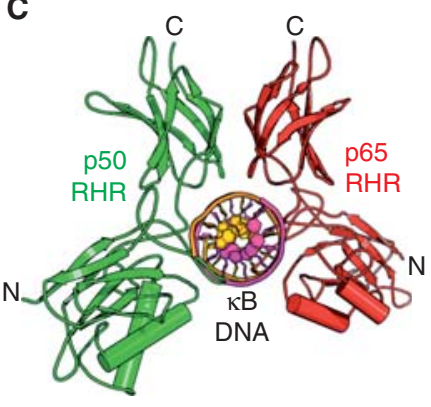

D

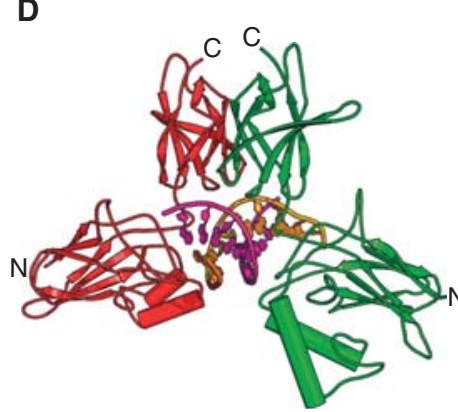

B

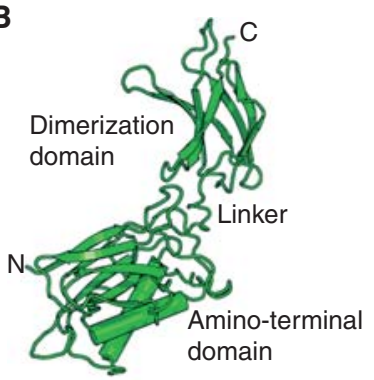

E

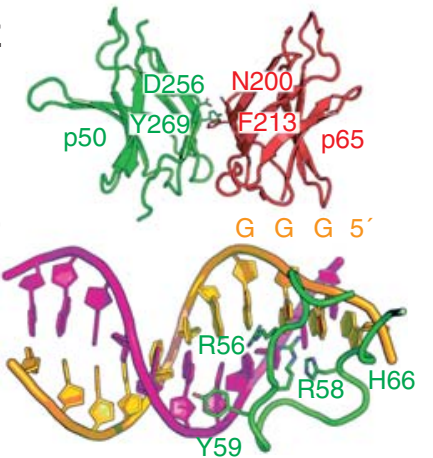

Figure 2. The NF-кB family. (A) The human genome encodes five polypeptides that assemble in various dimer combinations to form active NF- $\kappa \mathrm{B}$ transcription factors. Each of the subunits contains the Rel homology region (RHR) near its amino terminus. The RHR consists of two folded domains, the amino-terminal domain (NTD) and the dimerization domain (DimD), that are joined by a short flexible linker and a carboxy-terminal flexible region that contains the nuclear localization signal (L). Three of the subunits, p65, c-Rel, and RelB, also contain a transcription activation domain (TAD) at their carboxy-terminal ends. RelB contains a predicted leucine zipper motif (LZ) amino-terminal to its RHR. The NF- $\mathrm{KB}$ subunits $\mathrm{p} 50$ and $\mathrm{p} 52$ lack transactivation domains and have glycine-rich regions $(\mathrm{G})$. $(B)$ A ribbon diagram representation of the RHR from p50 in its DNA-bound conformation. $(C)$ The NF- $\kappa$ B p50:p65/RelA heterodimer bound to $\kappa \mathrm{B}$ DNA. $(D)$ Another view of the complex. (E) The NF-кB p50:p65/RelA heterodimer dimerization domains with key amino acid side chains labeled. $(F) \kappa B$ DNA from the NF-кB:DNA complex with key base-contacting amino acid residues labeled.

RelB also contains a predicted leucine zipper motif amino-terminal to its RHR. The NF$\kappa \mathrm{B}$ subunits p50 and p52 lack transactivation domains. Rather, their extreme carboxyterminal ends are rich in glycine. Consequently, NF- $\kappa \mathrm{B}$ dimers consisting exclusively of p50 and $\mathrm{p} 52$ subunits are capable of nuclear localization and DNA binding but fail to activate target gene expression and, in fact, function both in vitro and in vivo as repressors of transcription (Franzoso et al. 1992).

\section{NF-кB Dimerization}

Assembly of individual NF- $\mathrm{B}$ subunits into dimers capable of sequence-specific DNA binding and activating target gene expression is mediated entirely by the dimerization domain. In theory, a total of 15 unique homoand heterodimers are possible from combinatorial dimerization of the five NF- $\mathrm{KB}$ subunits (Hoffmann et al. 2006). Of these, 12 have been identified in vivo. Three that are not known to exist are the RelB:RelB, RelB:c-Rel, and p52:c-Rel. However, of these three, only RelB homodimer fails to exist in vivo, and the status of the other two dimers is uncertain; they could exist under specialized conditions such as the p65/RelA:RelB heterodimer (Marienfeld et al. 2003).

The homo- and heterotropic interactions between NF-кB family subunits follow the 
central dogma of all protein-protein complexes: A set of amino acid residues from each polypeptide participate in direct contacts with one another, forming the interface, whereas a different set of residues present outside of the interface indirectly affects the stability of the interface by modulating the local environment. One of the most stable NF-кB dimer interfaces is created by the p50:p65/RelA heterodimer (Fig. 2D). The p50:p65/RelA heterodimer assembles with a significantly greater stability than either of the respective p50:p50 or p65/ RelA:p65/RelA homodimers (Huang et al. 1997). Differences in the amino acid sequences of p50 and p65/RelA at two positions partially explain the variation in dimerization stability observed in the three dimers. The positions of Tyr-269 and Asp-256 in p50 are occupied by Phe-213 and Asn-200, respectively, in p65. Within the heterodimer, the Asp and Asn approach one another symmetrically at the interface and stabilize the heterodimer through formation of a highly stable hydrogen bond. In contrast, in the homodimers, the juxtaposition of Asp-Asp and Asn-Asn at the interface are detrimental to dimer stability. Similarly, the hydroxyl group on Tyr-269 of p50 hydrogen bonds at the dimer interface, contributing to stabilization of both the p50:p50 homodimer as well as the p50:p65/RelA heterodimer. The substitution of Phe at this position serves to weaken the p65/RelA:p65/RelA homodimer relative to the other two. Taken together, these observations help to explain why the p65/ RelA:p65/RelA homodimer forms with lower stability than does the p50:p50 homodimer and why the p50:p65/RelA heterodimer is more stable than both homodimers.

However, direct contact between complementary amino acids at the interface fails to completely explain the observed trends of $\mathrm{NF}-\mathrm{\kappa B}$ subunit dimerization. Mutation of noninterfacial residues contained within the dimerization domain has been shown to modulate dimerization. For example, changing p65/RelA Cys-216 to Ala affects homodimer formation (Ganchi et al. 1993). The role of noninterfacial amino acid residues in dimerization is most strikingly illustrated in the case of RelB. All interfacial residues in RelB are either identical or homologous to those of other NF-кB subunits. And yet, RelB assembles into a completely unique domain-swapped homodimer (Huang et al. 2005). Domain swapping occurs as a consequence of the destabilization of the folded RelB dimerization domain, suggesting that domain stability is an important determinant of protein-protein interaction. In cells, decreased folding stability in both the aminoterminal and dimerization domains contributes to its degradation by the proteasome, which explains why the RelB homodimer does not exist in vivo (Marienfeld et al. 2001).

Post-translational modification may also play a role in modulating dimerization propensity. One study has shown that RelB forms a dimer with a p65/RelA that is phosphorylated at position Ser-276 (Jacque et al. 2005). This serine is located in a loop within the dimerization domain, projected away from the dimer interface. It is unclear as to how phosphorylation of this serine positively impacts p65/ RelA:RelB heterodimer formation. One explanation could be that the increased negative charge may indirectly modulate dimer-forming residues of both p65/RelA and RelB.

\section{NF-кB Recognition of $\kappa B$ DNA}

$\mathrm{X}$-ray structures of NF- $\mathrm{BB}$ in complex with $\kappa B$ DNA revealed a new mode of DNA recognition wherein a dimer composed of the RHR of two NF- $\mathrm{BB}$ subunits intimately contacts double-stranded DNA within the major groove through one complete turn (Ghosh et al. 1995; Müller et al. 1995). NF-кB employs both its amino-terminal and dimerization domains to encircle its target DNA. DNA contacts are mediated by amino acids emanating from loops that connect $\beta$-strand elements of secondary protein structure. The p50:p50 homodimer structures revealed that this NF- $\mathrm{KB}$ subunit employs its amino acids His-66, Arg-58, and Arg-56 to contact three guanine nucleotide bases at the extreme $5^{\prime}$ ends of its consensus $\kappa B$ DNA. However, X-ray analyses of NF- $\kappa B$ p65/RelA:p65/RelA homodimers bound to $\kappa B$ DNA revealed that, when bound to a canonical 
10-base-pair $\kappa B$ DNA, one p65/RelA subunit contacts DNA in an analogous manner as observed in the p50 homodimer structures, whereas the second p65/RelA subunit significantly repositions its entire amino-terminal domain to mediate interactions with the DNA backbone (Chen et al. 1998b). Such a binding mode, which is afforded by flexibility in the short linker region that connects the two structured domains of the RHR, preserves binding affinity at the cost of fewer contacts to DNA bases. A close inspection of the homodimer:DNA complex structures leads to the suggestion that a homodimer of p50 might optimally bind to an 11-base-pair sequence composed of two 5'-GGGPuN half sites bracketing a central A:T base pair. In contrast, the NF-кB p65/RelA homodimer optimally recognizes a nine-base-pair target sequence containing two 5'-GGPuN half sites and a central A:T base pair. Determination of a second X-ray structure of NF- $\kappa \mathrm{B}$ p65/RelA homodimer in complex with the $\kappa \mathrm{B}$ DNA sequence from the promoter of IL-8 (5'-GGAA T TTCC-3') confirmed this hypothesis (Chen et al. 2000).

The lessons learned from structural analyses of p50 and p65/RelA homodimers bound to diverse $\kappa B$ DNA sequences suggested that the canonical NF- $\kappa$ B p50:p65/RelA heterodimer might recognize its 10 -base-pair target sequence with the p50 subunit binding specifically to a $5^{\prime}$-GGGPyN half site, whereas the p65/RelA subunit binds to a $5^{\prime}$-GGPyN half site separated from the p50 site by one A:T base pair. X-ray structure determination of a p50:p65/RelA RHR heterodimer bound to $\kappa B$ DNA from the original $\kappa$ light chain gene promoter, which is identical to a $\mathrm{\kappa B}$ sequence that is present in the promoter of HIV genome (5'-GGGAC T TTCC-3'), served to confirm this speculation (Chen et al. 1998a). Additional crystal structures of NF- $\mathrm{B}$ p50: p65/RelA heterodimer bound to different $\kappa \mathrm{B}$ DNA further support the basic rules of DNA half-site recognition developed from the homodimer:DNA structures (Berkowitz et al. 2002; Escalante et al. 2002).

$\mathrm{X}$-ray crystal structures of several additional NF-кB:DNA complexes have now been determined (Cramer et al. 1997; Cramer et al. 1999; Moorthy et al. 2007; Panne et al. 2007; Fusco et al. 2009). Taken together, these structures suggest a model for how NF- $\kappa \mathrm{B}$ dimers recognize $\kappa B$ DNA that contain significant deviations from the consensus sequence. Changes of $\kappa \mathrm{B}$ DNA sequence can be of two types. In the first, alteration occurs within the G:C base pairs that occupy positions on the outside of the $\kappa \mathrm{B}$ DNA and that are directly contacted by the amino-terminal domain. An example is the altered $\kappa \mathrm{B}$ sequence $5^{\prime}$-GGGAC T TTTC- $3^{\prime}$ (change from immunoglobin $\kappa \mathrm{B}$ sequence is underlined). Because of the loss of an important $\mathrm{C}$ : $\mathrm{G}$ base pair, the NF- $\mathrm{B}$ p65/RelA subunit conformation when bound to TTCC- $3^{\prime}$ is drastically different than to TTTC-3'. The flexible linker region and modular domain architecture within the RHR allows the amino-terminal domain to reposition itself and bind the DNA backbone to accommodate such variations in $\kappa \mathrm{B}$ DNA sequence. $A$ second type of $\kappa \mathrm{B}$ DNA sequence alteration involves changes within the central five base pairs. Of these, the central A:T is not directly contacted by the protein and the others are recognized nonspecifically through van der Waals contacts by p50 Tyr-59 (Tyr-36 in p65/ RelA). The third base pair from the $5^{\prime}$-end or its symmetric pair are less sensitive to change, as illustrated by a comparison of immunoglobin $\kappa \mathrm{B}$ and IFN- $\beta \kappa \mathrm{B}$ sequences $\left(5^{\prime}\right.$-GGGAC T TTCC- $3^{\prime}$ and $5^{\prime}$-GGGAA T TTCC- $3^{\prime}$, respectively). The C:G to A:T base-pair change does not affect DNA recognition by the protein but may influence stability of binding because of the more rigid DNA structure of IFN- $\beta \kappa B$ sites. In this second case, overall conformations of the protein:DNA complexes are similar, but binding affinity could differ significantly.

Molecular dynamics simulations have revealed intriguing structural transitions of a 20 base-pair DNA containing the $\kappa \mathrm{B}$ site of IL-2 promoter (AGAA A TTCC). The central A:T base pair (underlined) undergoes cross-stand stacking and the central A:T base pair flips out of the DNA axis (Mura and McCammon 2008). This dynamic behavior of the DNA suggests a highly complex mechanism of DNA 
recognition by the $\mathrm{NF}-\kappa \mathrm{B}$ dimers, in which DNA sequence variations may play a significant role in the recognition process. In general, one can confidently say that the sequences at the center of $\mathrm{a} \kappa \mathrm{B}$ sequence may profoundly affect the binding affinity and specificity.

\section{ІКB}

\section{Introduction to $I_{\kappa} \mathrm{B}$}

Almost immediately on detecting NF-кB in immune cells, researchers discovered that a latent $\kappa \mathrm{B}$ DNA binding activity was present in the cytoplasm of all resting cells and that this pool of NF- $\kappa$ B could be activated by treatment of cell lysates with the weak detergent deoxycholate (Baeuerle and Baltimore 1988a). This suggested that noncovalent interaction with an inhibitor protein was responsible for maintaining NF- $\kappa \mathrm{B}$ in an inactive state. Purification of the inhibitor activity led to the cloning of the inhibitory proteins IкB $\alpha$ and IкB $\beta$ (Baeuerle and Baltimore 1988b; Thompson et al. 1995). A third IкB gene was later identified by sequence homology in an EST database and was called IкBe (Li and Nabel 1997; Simeonidis et al.
1997; Whiteside et al. 1997). Subsequent experiments demonstrated that it also exhibits NF- $\mathrm{B}$ inhibitory activity.

\section{Classical ІкB Sequence and Structure}

Both $\mathrm{I} \kappa \mathrm{B} \alpha$ and $\mathrm{I} \kappa \mathrm{B} \beta$, as well as the more recently discovered $\mathrm{I} \kappa \mathrm{B} \varepsilon$, contain a central ankyrin repeat domain (ARD) that contains six ankyrin repeats (Fig. 3A). The ankyrin repeat (ANK) is a roughly 33-amino-acid consensus amino acid sequence that appears in multiple copies in numerous proteins (Fig. 3B) (Sedgwick and Smerdon 1999). Ankyrin repeats are part of a greater superfamily of helical repeat motifs, which include HEAT repeats, armadillo repeats, and leucine-rich repeats, and are common to proteins involved in protein-protein interactions (Groves and Barford 1999). At their amino-terminal ends, classical I $\mathrm{KB}$ proteins contain a sequence of amino acids that do not adopt a folded structure in solution (Jaffray et al. 1995). Contained within this signal response region are the conserved serine sites of phosphorylation by IKK. Roughly 10 amino acids amino-terminal to this pair of serines
A

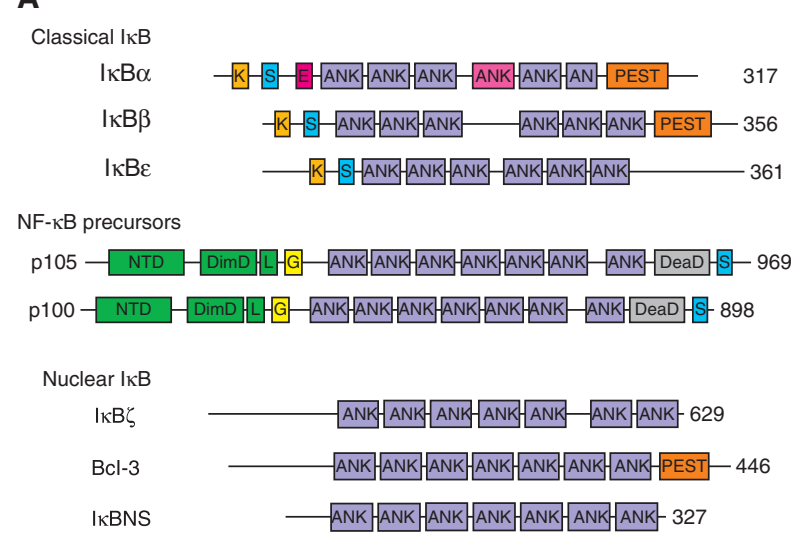

B

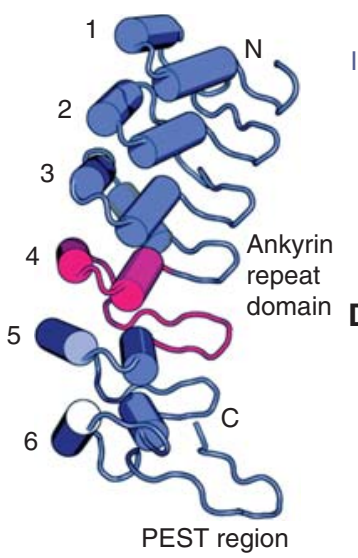

C

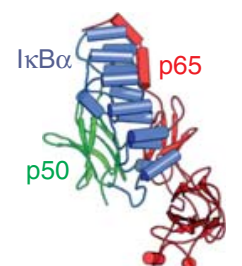

Figure 3. The family of human IкB proteins. (A) ІкB proteins are classified as in text. Classical IкB proteins possess ankyrin repeats (ANK) flanked by an amino-terminal signal response region and carboxy terminal PEST region. The signal response regions contain sites of phosphorylation by IKK (S), ubiquitination (K), and nuclear export (E). The NF- $\kappa$ B precursors serve as IкB proteins as well as the source of the mature p50 and p52 NF- $\kappa$ B subunits. (B) Ribbon diagram of the I $\mathrm{B} \alpha$ structure from the NF- $\kappa \mathrm{B}: \mathrm{I} \kappa \mathrm{B} \alpha$ complex crystal structure. Individual ankyrin repeats are numbered, ANK 4 is colored magenta, and the PEST region is labeled. $(C)$ Ribbon diagram of the NF-кB:IкB $\alpha$ complex. $(D)$ Another view of the complex. 
reside conserved lysine amino acid sites of polyubiquitination. This amino-terminal region of Ік $\mathrm{B} \alpha$ also contains a functional nuclear export sequence (Johnson et al. 1999; Huang et al. 2000). It is not masked on binding to NF- $\kappa B$ and contributes to the observed cytoplasmic localization of NF-кB:IкB $\alpha$ complexes. Neither $\mathrm{I} \kappa \mathrm{B} \beta$ nor $\mathrm{I} \kappa \mathrm{B} \varepsilon$ possess this inherent nuclear export potential. Consequently, stable NF-кB:IкB $\beta$ complexes reside stably either in the cytoplasm or the nucleus, whereas appears to function as a negative feedback regulator of cytoplasmic NF-кB (Malek et al. 2001; Tam and Sen 2001; Kearns et al. 2006). At their carboxy-terminal ends, the three classical IкB proteins contain a short sequence rich in the amino acids proline, glutamic acid, serine, and threonine. This so-called PEST region is common to many proteins that, like IкB, display rapid turnover in cells (Rogers et al. 1986; Pando and Verma 2000). The PEST region of $\mathrm{I} \kappa \mathrm{B} \alpha$, however, is also required for its ability to disrupt preformed NF- $\mathrm{B}$ :DNA complexes (Ernst et al. 1995).

\section{ІкB Interactions with NF-кB}

The X-ray structure of $\mathrm{I} \kappa \mathrm{B} \alpha$ in complex with the NF-кB p50:p65/RelA heterodimer was determined independently by two separate laboratories in 1998 (Huxford et al. 1998; Jacobs and Harrison 1998). Both groups relied on a similar strategy of removing the signal response region of $\mathrm{I} \kappa \mathrm{B} \alpha$ and the amino-terminal domain of the p50 subunit to stabilize the conformationally dynamic complex for cocrystallization (Huxford et al. 2000). The structure reveals how Iк $\mathrm{B} \alpha$ uses its entire ankyrin repeatcontaining domain as well as its carboxyterminal PEST sequence to mediate an extensive protein-protein interface of roughly $4300 \AA^{2}$ (Fig. 3C,D). The carboxy-terminal 30 amino acids from the NF-кB p65/RelA subunit RHR, which were disordered in NF- $\kappa$ B:DNA complex structures, adopt an ordered helical structure that contacts the first two ankyrin repeats and forms significant hydrophobic contacts with the amino-terminal face of the $\mathrm{I} \kappa \mathrm{B} \alpha$ ankyrin repeat stack. This interaction masks the p65/RelA nuclear localization signal. Ankyrin repeats three through five participate in multiple van der Waals contacts with one surface of the p50:p65/RelA heterodimer dimerization domains. The sixth ankyrin repeat and PEST region of IкB $\alpha$ present a vast acidic patch, which opposes the largely positively charged DNA binding surfaces of the p65/ RelA amino-terminal domain. As a consequence of this electrostatic interaction, the p65/RelA amino-terminal domain occupies a position relative to the dimerization domain that is rotated roughly $180^{\circ}$ and translated 40 Å when compared with its DNA bound structures. The transition of p65/RelA to the conformation observed in the NF-кB:IкB complex does not disrupt the amino-terminal domain structure and is afforded entirely by the flexible linker region that connects the amino-terminal and dimerization domains. The structure of a similar construct of I $\mathrm{B} \beta \beta$ bound to the dimerization domain from the NF-кB p65/ RelA:p65/RelA homodimer suggests that ІкB $\beta$ uses a similar strategy in binding to NF- $\mathrm{B}$, although it relies less on interactions with the p65/RelA amino-terminal domain for complex stability (Malek et al. 2003).

\section{ІкB $\alpha$ Dynamics}

Protein dynamics, or the rates with which a protein exchanges between quasi-stable folded states, is an extremely important aspect of protein structure and function. Several independent lines of investigation, including thermal and chemical denaturation, computer simulations, NMR spectroscopy, and failed crystallization attempts, have led to the conclusion that the IкB $\alpha$ protein exhibits a high degree of structural dynamics in solution (Huxford et al. 2000; Pando and Verma 2000; Croy et al. 2004; Bergqvist et al. 2006). This runs counter to the data that have emerged from protein engineering studies that clearly show that ankyrin repeat proteins designed after consensus sequences or those that appear in nature are extremely stably folded (Binz et al. 2003; Binz et al. 2004). IкB $\alpha$ has, therefore, evolved as an inherently unstable ankyrin repeat-containing 
protein. The consequences of this are twofold.

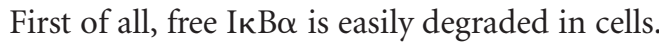
This signal-independent degradation involves the 20S proteasome and the carboxy-terminal PEST of IкB $\alpha$ (Mathes et al. 2008). Moreover, recent computational modeling of the NF- $\kappa B$ pathway through a systems biology approach has confirmed that regulation of NF- $\kappa \mathrm{B}$ activation can be controlled by small changes in the rate of degradation of a constitutively expressed free cytoplasmic I $\mathrm{I} B \alpha$ (O'Dea et al.

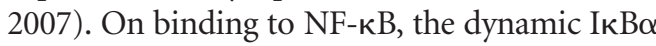
ankyrin repeat fold becomes stable and the PEST region protein turnover signal sequence is adopted as a DNA-inhibitory functional element (Sue et al. 2008). Degradation of I $\mathrm{B} \alpha$ is shifted from the steady state to a signaldependent pathway that requires phosphorylation within the flexible amino-terminal signal response region. It is likely that the inherent folding instability of $\mathrm{I} \kappa \mathrm{B} \alpha$ contributes to it being targeted by the proteasome, whereas $\mathrm{NF}-\kappa \mathrm{B}$, which is composed of two stably folded domains and with which $\mathrm{I} \kappa \mathrm{B} \alpha$ is associated in a complex at subnanomolar dissociation binding constant, remains intact.

\section{Nonclassical ІкВ Proteins}

Through the efforts of investigators attempting to understand regulation of NF- $\mathrm{B}$, a more diverse family of $\mathrm{I} \kappa \mathrm{B}$ proteins has emerged. Proteins of the IкB family are all linked by the fact that they contain ankyrin repeats and interact with NF- $\kappa \mathrm{B}$ subunits to affect gene expression. The classical IкB proteins, I $\mathrm{B} \alpha$, I $\mathrm{B} \beta$, and $\mathrm{I} \kappa \mathrm{B} \varepsilon$, have been described. A second class of $\mathrm{I} \kappa \mathrm{B}$ proteins is represented by the NF- $\kappa \mathrm{B}$ precursor proteins p105 and p100 (Basak et al. 2007). These two proteins act both as precursors of NF- $\kappa$ B p50 and p52 subunits, respectively, and as inhibitors of NF- $\kappa B$ (Fig. 3A). The NF- $\kappa \mathrm{B}$ precursor proteins are responsible for inhibiting nearly half of the NF- $\kappa \mathrm{B}$ in resting cells. However, unlike classical I $\mathrm{B}$ proteins that inhibit NF- $\kappa \mathrm{B}$ by forming $1: 1$ complexes, these NF- $\kappa \mathrm{B}$ precursors participate in large multiprotein assemblies, wherein more than one NF- $\kappa \mathrm{B}$ dimer can bind to multiple p100 and/or p105 subunits. The assembly of p100 and p105 into larger complexes is mediated by an oligomerization domain located immediately amino-terminal to their ankyrin-repeat domains. This assembly is heterogeneous, i.e., several different NF- $\mathrm{B}$ subunits can be inhibited in a single inhibitory complex (Savinova et al. 2009). Therefore, stimulus-specific degradation of p100 or p105 can in principle release different NF- $\mathrm{B}$ dimers. Together, these dimers exhibit a much broader spectrum of gene regulatory activities (Savinova et al. 2009, Shih et al. 2009). The large heterogeneous NF-кB inhibitory complex assemblies have been dubbed NF- $\kappa$ Bsomes to distinguish them from the smaller NF- $\kappa \mathrm{B}$ inhibitory complexes formed by IкB $\alpha,-\beta$, and $-\varepsilon$.

Together with $\mathrm{I} \kappa \mathrm{B} \alpha$ and $\mathrm{I} \kappa \mathrm{B} \varepsilon$, the NF- $\kappa \mathrm{B}$ precursors are targets of NF- $\kappa \mathrm{B}$-driven transcription. Newly synthesized ІкB serve to block NF- $\kappa \mathrm{B}$ activity postinduction. This negative feedback regulation of $N F-\kappa B$ by I $\mathrm{B}$ proteins is critical for control of inflammation and other diseases (Hoffmann et al. 2002).

\section{Nuclear ІкB Proteins}

A third, entirely different class of IкB is represented by the proteins $\mathrm{Bcl}-3$, ІкB $\zeta / \mathrm{MAIL}$, and ІкBNS (Fig. 3A). Bcl-3 was cloned as a consequence to its proximity to a breakpoint mutation in some leukemias (Ohno et al. 1990). ІкB $\zeta$ was discovered in a screen of genes that displayed increased expression after induction of immune cells with bacterial lipopolysaccharide (LPS) or the inflammatory cytokine interleukin-1 (IL-1) (Kitamura et al. 2000; Haruta et al. 2001; Yamazaki et al. 2001). IкBNS was identified as a gene that is expressed in $\mathrm{T}$ cells during negative selection (Fiorini et al. 2002). Unlike classical IкB, these proteins do not contain amino-terminal signal-dependent phosphorylation sites or carboxy-terminal PEST regions. Their classification as "nuclear ІкB" derives from the fact that they contain ankyrin repeats, bind NF- $\mathrm{KB}$ subunits, and concentrate within the nucleus when expressed in cells (Michel et al. 2001). 
Each of the three nuclear $I \kappa \mathrm{B}$ proteins are themselves the products of NF- $\mathrm{B}$-dependent genes (Eto et al. 2003; Ge et al. 2003; Hirotani et al. 2005). They bind to NF-кB, but, whereas the classical $\mathrm{I} \kappa \mathrm{B}$ proteins prefer dimers that possess at least one p65/RelA or c-Rel subunit, or nonclassical p105 and p100 binds all NF-кB subunits, nuclear $\mathrm{I} \kappa \mathrm{Bs}$ bind specifically to homodimers of p50 (Hatada et al. 1992; Yamazaki et al. 2001; Trinh et al. 2008). Finally, association of nuclear I $\mathrm{B}$ proteins with nuclear NF- $\mathrm{B}$ can have diverse but important consequences on gene expression (Franzoso et al. 1992; Muta et al. 2003; Hirotani et al. 2005; Motoyama et al. 2005; Riemann et al. 2005). In peritoneal macrophages derived from mice lacking the gene encoding $\mathrm{I} \kappa \mathrm{B} \zeta$, for example, a complete inability to produce the NF- $\kappa \mathrm{B}$-dependent cytokine interleukin-6 (IL-6) in response to LPS treatment was observed (Yamamoto et al. 2004). As IL-6 is a gene that is expressed in a later phase of NF- $\mathrm{KB}$ induction, it is apparent that the early induction and nuclear accumulation of $\mathrm{I} \kappa \mathrm{B} \zeta$ plays a vital role in the LPS-dependent expression of this pluripotent cytokine.

\section{IKK}

\section{Introduction to IKK}

In a thrilling conclusion to a search to identify an enzymatic activity that was capable of phosphorylating the two serine amino acids of the signal response region of $\mathrm{I} \kappa \mathrm{B} \alpha$, researchers from three labs reported in 1997 the IкB Kinase complex (IKK) (DiDonato et al. 1997; Mercurio et al. 1997; Regnier et al. 1997). This IKK was purified from cytokine-induced HeLa cells and exhibited an apparent molecular mass of 700-900 kDa. Microsequencing revealed two related kinase domain-containing subunits, referred to as IKK $\alpha$ and IKK $\beta$ (or alternatively as IKK1 and IKK2, respectively) (DiDonato et al. 1997; Zandi et al. 1997). These exhibit molecular masses of 85 and $87 \mathrm{kDa}$, respectively, and display $50 \%$ identity at the amino-acid level. The IKK $\alpha$ subunit was recognized to be the same protein that was originally cloned in 1995 as CHUK, a kinase with homology to the helixloop-helix transcription factors, and IKK $\beta$ was subsequently identified as a hit in a yeast twohybrid screen with NIK, a kinase suspected to function upstream of IKK, as bait (Connelly and Marcu 1995; Regnier et al. 1997; Woronicz et al. 1997). A third subunit, known as IKK $\gamma$ (also known as NEMO), was also identified as a $49 \mathrm{kDa}$ member of the IKK complex (Rothwarf et al. 1998; Yamaoka et al. 1998; Li et al. 1999b; Mercurio et al. 1999).

The function of IKK $1 / \mathrm{IKK} \alpha$ in cells is somewhat exotic and continues to be elucidated (Hu et al. 2001; Senftleben et al. 2001; Anest et al. 2003; Yamamoto et al. 2003; Sil et al. 2004; Lawrence et al. 2005). However, multiple studies including mouse knockouts have revealed that IKK2/IKK $\beta$ is responsible for phosphorylating I $\mathrm{IB}$ in response to NF- $\kappa \mathrm{B}$ inducing signals ( $\mathrm{Li}$ et al. 1999a; Li et al. 1999c; Tanaka et al. 1999). Because of its role as the primary inducer of the NF- $\kappa \mathrm{B}$ transcription factor, IKK $2 / \mathrm{IKK} \beta$ plays the critical role in promoting inflammation and cell survival in response to proinflammatory stimuli. The NEMO/IKKy subunit does not possess any kinase domain or enzymatic activity and instead it acts as an adapter subunit that links the catalytic subunits to receptor proximal signaling molecules. Mouse knockout studies clearly reveal that proper NF- $\mathrm{NB}$ signaling through IKK is not possible without this subunit (Makris et al. 2000; Rudolph et al. 2000; Schmidt-Supprian et al. 2000).

\section{IKK Catalytic Subunit Domain Organization}

The IKK $1 / \mathrm{IKK} \alpha$ and IKK2/IKK $\beta$ subunits exhibit an uncommon domain organization (Fig. 4A). Their first roughly 300 amino acids contain a clearly recognizable kinase domain. This is followed by a short region that exhibits distant homology to ubiquitin (Ikeda et al. 2007). A central region contains a leucine zipper motif followed by a region with slight homology to the helix-loop-helix transcription factors. This is followed by a serine-rich region. Finally, the carboxy-terminal element of IKK $\beta$ 
A
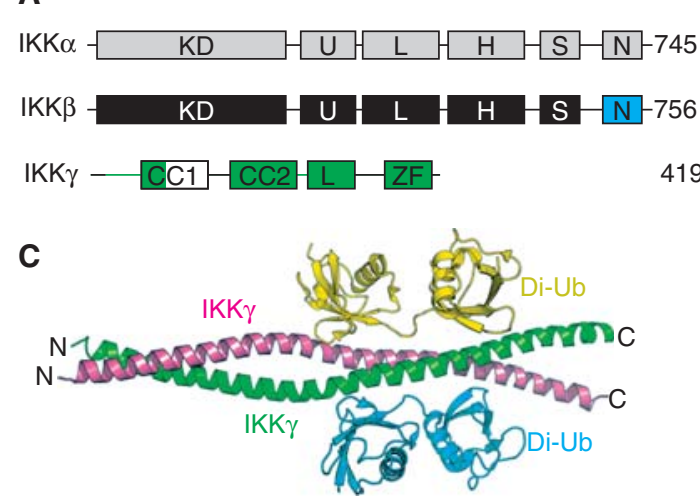

B

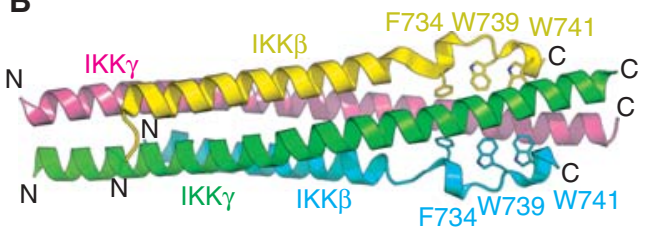

D

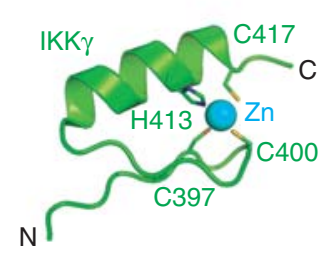

Figure 4. Subunits of the human IKK complex. (A) Domain organization of IKK subunits. Catalytic subunits contain a kinase domain (KD), ubiquitin-like domain (U), leucine zipper (L), helix-loop-helix (H), serine-rich (S), and NEMO-binding motif $(\mathrm{N})$. The NEMO/IKK $\gamma$ subunit contains two predicted coiled-coil motifs (CC1 and -2), a leucine zipper (L), and a carboxy-terminal zinc-finger (ZF). (B) Ribbon diagram of the IKK2/IKK $\beta$ :NEMO/IKK $\gamma$ complex. Individual polypeptides are labeled as well as some of the conserved hydrophobic amino acid side chains from IKK2/IKK $\beta$. (C) Ribbon diagram of the NEMO/ IKK $\gamma$ :di-ubiquitin complex. $(D)$ The NEMO/IKK $\gamma$ carboxy-terminal zinc-finger motif structure.

has been shown to interact directly with NEMO/IKKy (May et al. 2000; May et al. 2002). A genome-wide analysis has identified a small clade of proteins with domain organization reminiscent of the catalytic IKK1/IKK $\alpha$ and IKK2/IKK $\beta$ subunits (Manning et al. 2002). This kinase subgroup includes the proteins IKKe and TBK1/NAK. Both have been characterized as upstream modulators of IKK activity and are, therefore, both structurally and functionally related to the catalytic IKK subunits (Tojima et al. 2000; Peters and Maniatis 2001).

With the exception of the extreme carboxyterminal NEMO/IKK $\gamma$-interacting motif, the structures of IKK1/IKK $\alpha$ and IKK2/IKK $\beta$ are unknown. Although it is clear that the kinase domain of IKK2/IKK $\beta$ is necessary for catalyzing phospho-transfer, regions of the protein outside of this domain are necessary for directing specificity to the amino-terminal serines of IкB $\alpha$. Deletion of the leucine zipper and helix-loop-helix has been shown to yield a mutant enzyme that, although it is capable of catalyzing phospho-transfer to $\operatorname{I} \kappa \mathrm{B} \alpha$, fails to recognize the amino-terminal serines required for NF- $\kappa \mathrm{B}$ activation in response to inflammatory signaling (Shaul et al. 2008).

\section{NEMO/IKK $\gamma$ Domain Organization}

Structural interest in NEMO/IKK $\gamma$ arises from its lack of a kinase domain or, for that matter, homology to any other protein of known structure. Secondary-structure prediction methods suggest that NEMO/IKK $\gamma$ is a mostly helical protein with two signature coiled coil (CC) elements and a leucine zipper motif in the middle are flanked by a helical dimerization domain near the amino-terminal end and a Zn-finger motif at the carboxyl terminus. Three-dimensional structures of several fragments of the NEMO/IKK $\gamma$ subunit either as free polypeptides or bound to ligands have recently been elucidated. These NEMO/IKK $\gamma$ structures allow one to envision that with the exception of the very ends, NEMO/IKK $\gamma$ consists of long helices that are punctuated by short unstructured regions. These helical segments wrap around each other forming a long coiled-coil dimer with fraying of the monomers at each end. The carboxy-terminal end contains a $\mathrm{Zn}$-finger motif and the 40-residue long amino terminus is likely to be flexible and unstructured.

The NEMO/IKK $\gamma$ fragment structures suggest how IKK $\gamma$ might be involved in 
cellular signaling. NEMO/IKK $\gamma$ was previously thought to form a multimer with different segments shown to form dimers, trimers, or tetramers (Agou et al. 2002; Tegethoff et al. 2003; Marienfeld et al. 2006; Drew et al. 2007; Herscovitch et al. 2008). With new structural information, it now appears that previous conclusions might not be accurate. It is not surprising as flexible coiled-coil motifs migrate through the gel filtration beads differently than the stably folded globular proteins of identical mass.

\section{Two Distinct IKK Activation Pathways}

The IKK1/IKK $\alpha$ and IKK2/IKK $\beta$ subunits are activated through distinct signaling pathways (Senftleben et al. 2001). These pathways are activated by two distinct sets of stimuli. The canonical pathway is triggered by LPS or inflammatory cytokines TNF- $\alpha$ or IL- 1 and signals through IKK2/IKK $\beta$ to activate p65/ RelA and c-Rel dimers through the degradation

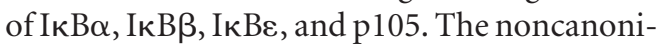
cal pathway results from BAFF, LT- $\beta$, and CD40 signaling through IKK $\alpha$, leading to activation of the $\mathrm{p} 52$ :RelB heterodimer through processing of p100 into p52 (Ghosh and Karin 2002). Activation of both pathways requires interactions of signaling molecules through specific poly-ubiquitin moieties that are covalently linked to some of these molecules. In addition, upstream protein kinases are also essential for activation of both kinases. The major distinction between these two pathways is the involvement of a single upstream kinase, known as $\mathrm{NF}-\kappa \mathrm{B}$ inducing kinase (NIK), to activate $\mathrm{IKK} \alpha$, whereas multiple kinases can activate IKK $\beta$. IKK $\alpha$ and IKK $\beta$ are both present in the same particle in vivo. One puzzling question, however, is whether the different pathways target these two distinct subunits in a single complex or if there is a separate pool of IKK $\alpha$ present in cells that is activated by the noncanonical pathway. For the canonical pathway, however, the IKK $\beta$ subunit of the heterodimer must be activated. The role for IKK $\alpha$ in canonical signaling is unclear. The presence of the IкB kinases in multiple signaling pathways suggests that they are capable of participating in diverse signaling complexes throughout the cell.

\section{IKK Complex Oligomerization}

Although several combinations of the IKK1/ IKK $\alpha$, IKK $2 / \mathrm{IKK} \beta$, and NEMO/IKK $\gamma$ subunits have been proposed to account for the original 700-900 kDa complex, no successful reconstitution from purified components has resulted in an active complex of this size. Therefore, 10 years after isolation of the complex, even the oligomerization state of the IKK complex remains unclear. Given the presence of multiple conserved elements that can potentially mediate homo- and heteromeric interactions between subunits, there exist many possibilities. Early attempts to determine the arrangement of subunits in the complex led to the model that, independent of its NEMO/ IKK $\gamma$ scaffolding protein, IKK $1 / \mathrm{IKK} \alpha$ and IKK $2 /$ IKK $\beta$ are capable of forming stable homo- or heterodimers (Zandi et al. 1998). More recent work with human IKK $2 / \mathrm{IKK} \beta$ purified in milligram quantities from recombinant baculovirus-infected sf9 insect cells has shown that the full length subunit purifies as a tetramer. Removal of the carboxy-terminal 100 amino acids containing the serine-rich and NEMO/IKK $\gamma$-binding regions results in a dimeric enzyme, whereas removal of the entire carboxy-terminal portion beginning at the leucine zipper renders the kinase monomeric. Interestingly, it was observed that although this monomeric IKK2/IKK $\beta$ kinase domain remains catalytically active, it fails to specifically phosphorylate the signal response region of I $\mathrm{B} \alpha$ and instead catalyzes phosphorylation of the PEST (Shaul et al. 2008). The presence of multiple domains linked to flexibility in all three subunits shows why it is difficult to structurally characterize functional IKK complexes.

\section{The Emerging Structure of NEMO/IKK $\gamma$}

A working structural model of the NEMO/ IKK $\gamma$ subunit has begun to take shape with the recent successful determination of several X-ray and NMR structures of discrete functional 
portions. The structure of an IKK2/IKK $\beta$ polypeptide bound the amino-terminal helical region (residues 44 to 111 ) of $\mathrm{NEMO} / \mathrm{IKK} \gamma$ revealed the complex forms a parallel four-helix bundle where two IKK2/IKK $\beta$ peptides associate with the NEMO/IKK $\gamma$ dimer (Rushe et al. 2008). The IKK $2 /$ IKK $\beta$ peptides appear to fold on binding to the NEMO/IKK $\gamma$-dimer scaffold, making several contacts (Fig. 4B). The affinity of interaction between NEMO/IKK $\gamma$ and IKK2/IKK $\beta$ subcomplex is high $\left(K_{\mathrm{D}}\right.$ is in low nanomolar range) and requires a large array of contacts. However, few of the hydrophobic residues in IKK2/IKK $\beta$ that are observed to line the hydrophobic pocket formed by the NEMO/ IKK $y$ dimer are required for complex formation. Although no clear experimental data is available, the IKK:IKK $\gamma$ complexes might exist as a $2: 2$ complex, where a dimeric NEMO/IKK $\gamma$ binds to an IKK dimer. The amino-terminal helical dimerization domain of NEMO/IKK $\gamma$ interacts with both the IKK1/IKK $\alpha$ and IKK2/IKK $\beta$ carboxy-terminal peptides, forming a 1:1:2 (IKK1/IKK $\alpha: I K K 2 / I K K \beta: N E M O / I K K \gamma)$ IKK complex. This is possibly the basal state of the IKK complex in cells.

Several reports demonstrated an interaction between poly-ubiquitin chains and the CC2LZ region of NEMO/IKKy (Lo et al. 2009). Although its was previously thought that the poly-ubiquitin chain is linked through lysine 63 and glycine 76 of ubiquitin, experiments have now shown that linear ubiquitin chains bind to NEMO/IKK $\gamma$ with 100-fold tighter binding affinity than do K63-linked chains. The X-ray structure of the complex between the CC2-LZ of NEMO/IKK $\gamma$ and a linear di-ubiquitin motif has been recently elucidated (Rahighi et al. 2009). Two di-ubiquitin motifs are bound to two chains of the LZ motif (Fig. 4C). It is striking that this central region of $\mathrm{NEMO} / \mathrm{IKK} \gamma$ also exhibits the elongated coiled-coil motif that was observed in the previously determined IKK2/IKK $\beta$ :NEMO/IKK $\gamma$ complex as well as in the $\mathrm{X}$-ray structure of a complex between the carboxy-terminal helical region of NEMO/IKK $\gamma$ and the viral protein vFLIP from Kaposi's sarcoma virus (Bagnéris et al. 2008).
The extreme carboxy-terminal region of NEMO/IKK $\gamma$ adopts a CCHC-type zinc-finger motif. The solution structure of this region has been determined by multidimensional NMR spectroscopy (Cordier et al. 2008). Its structure adopts the familiar fold of a zinc-finger motif (Fig. 4d). Furthermore, this motif has been characterized as a ubiquitin-binding motif required for NF- $\mathrm{KB}$ signaling in response to TNF- $\alpha$ (Cordier et al. 2009).

When taken together, the NEMO/IKK $\gamma$ substructures suggest that this subunit adopts an elongated helical structure. Two long helices bind one another through extended coiled-coil interactions to form the docking site for a pair of kinase subunits at the amino terminus, binding sites for di-ubiquitin and other proteins throughout the central region, and a pair of zinc-finger ubiquitin binding sites at the carboxyl terminus. This modular arrangement of docking sites for diverse proteins seems appropriate for a subunit that is thought to function principally as a scaffold for inducible signaling. Although significant structural work on IKK complexes remains to be carried out, this oddly elongated NEMO/ IKK $\gamma$ model serves to explain some of the complications associated with early studies that relied primarily on size exclusion chromatography for characterization of complex size and subunit stoichiometry.

\section{ACKNOWLEDGMENTS}

T.H. is supported by American Cancer Society grant RSG-08-287-01-GMC. G.G. is supported by National Institutes of Health $(\mathrm{NIH})$ grants (GM085490, AI064326, and NCI141722).

\section{REFERENCES}

\footnotetext{
Agou F, Ye F, Goffinont S, Courtois G, Yamaoka S, Isräel A, Véron M. 2002. NEMO trimerizes through its coiledcoiled C-terminal domain. J Biol Chem 277: $17464-17475$.

Anest V, Hanson JL, Cogswell PC, Steinbrecher KA, Strahl BD, Baldwin AS. 2003. A nucleosomal function for IкB kinase- $\alpha$ in NF-кB-dependent gene expression. Nature 423: 659-663.
} 
Baeuerle PA, Baltimore D. 1988a. Activation of DNAbinding activity in an apparently cytoplasmic precursor of the NF-кB transcription factor. Cell 53: 211-217.

Baeuerle PA, Baltimore D. 1988b. IкB: A specific inhibitor of the NF- $\mathrm{KB}$ transcription factor. Science 242: $540-546$

Bagnéris C, Ageichik AV, Cronin N, Wallace B, Collins M, Boshoff C, Waksman G, Barrett T. 2008. Crystal structure of a vFlip-IKK $\gamma$ complex: Insights into viral activation of the IKK signalosome. Mol Cell 30: 620-631.

Baltimore D, Beg AA. 1995. DNA-binding proteins. A butterfly flutters by. Nature 373: 287-288.

Basak S, Kim H, Kearns JD, Tergaonkar V, O’Dea E, Werner SL, Benedict CA, Ware CF, Ghosh G, Verma IM, Hoffmann A. 2007. A fourth IкB protein within the NF- $\mathrm{BB}$ signaling module. Cell 128: 369-381.

Bergqvist S, Croy CH, Kjaergaard M, Huxford T, Ghosh G, Komives EA. 2006. Thermodynamics Reveal that Helix Four in the NLS of NF- $\kappa B$ p 65 Anchors I $\kappa \beta \alpha$, Forming a Very Stable Complex. J Mol Biol 360: 421-434.

Berkowitz B, Huang DB, Chen-Park FE, Sigler PB, Ghosh G 2002. The $\mathrm{x}$-ray crystal structure of the NF-kB p50:p65 heterodimer bound to the interferon- $\beta \kappa \mathrm{B}$ site. $J$ Biol Chem 277: 24694-24700.

Binz HK, Amstutz P, Kohl A, Stumpp MT, Briand C, Forrer P, Grütter MG, Plückthun A. 2004. High-affinity binders selected from designed ankyrin repeat protein libraries. Nat Biotechnol 22: 575-582.

Binz HK, Stumpp MT, Forrer P, Amstutz P, Plückthun A 2003. Designing repeat proteins: Well-expressed, soluble and stable proteins from combinatorial libraries of consensus ankyrin repeat proteins. J Mol Biol 332: 489-503.

Chen YQ, Ghosh S, Ghosh G. 1998b. A novel DNA recognition mode by the NF-кB p65 homodimer. Nat Struct Biol 5: 67-73.

Chen FE, Huang DB, Chen YQ, Ghosh G. 1998a. Crystal structure of $\mathrm{p} 50 / \mathrm{p} 65$ heterodimer of transcription factor NF- $\kappa$ B bound to DNA Nature 391: 410-413.

Chen YQ, Sengchanthalangsy LL, Hackett A, Ghosh G. 2000 NF- $\kappa$ B p65 (RelA) homodimer uses distinct mechanisms to recognize DNA targets. Structure 8: 419-428.

Connelly MA, Marcu KB. 1995. CHUK, a new member of the helix-loop-helix and leucine zipper families of interacting proteins, contains a serine-threonine kinase catalytic domain. Cell Mol Biol Res 41: 537-549.

Cordier F, Grubisha O, Traincard F, Véron M, Delepierre M, Agou F. 2009. The zinc finger of NEMO is a functional ubiquitin-binding domain. J Biol Chem 284: 2902-2907.

Cordier F, Vinolo E, Véron M, Delepierre M, Agou F. 2008. Solution structure of NEMO zinc finger and impact of an anhidrotic ectodermal dysplasia with immunodeficiency-related point mutation. J Mol Biol 377: 1419-1432.

Cramer P, Larson CJ, Verdine GL, Müller CW. 1997. Structure of the human NF-кB p52 homodimer-DNA complex at $2.1 \AA$ resolution. EMBO J 16: 7078-7090.

Cramer P, Varrot A, Barillas-Mury C, Kafatos FC, Müller CW. 1999. Structure of the specificity domain of the Dorsal homologue Gambif1 bound to DNA Structure 7: $841-852$.

Croy CH, Bergqvist S, Huxford T, Ghosh G, Komives EA. 2004. Biophysical characterization of the free ІкBa ankyrin repeat domain in solution. Protein Sci 13: 1767-1777.

DiDonato JA, Hayakawa M, Rothwarf DM, Zandi E, Karin M. 1997. A cytokine-responsive IкB kinase that activates the transcription factor NF-кB Nature 388: 548-554.

Drew D, Shimada E, Huynh K, Bergqvist S, Talwar R, Karin M, Ghosh G. 2007. Inhibitor кB kinase $\beta$ binding by inhibitor кB kinase $\gamma$. Biochemistry 46: 12482-12490.

Ernst MK, Dunn LL, Rice NR. 1995. The PEST-like sequence of IкB $\alpha$ is responsible for inhibition of DNA binding but not for cytoplasmic retention of c-Rel or RelA homodimers. Mol Cell Biol 15: 872-882.

Escalante CR, Shen L, Thanos D, Aggarwal AK. 2002. Structure of NF- $\mathrm{kB}$ p50/p65 heterodimer bound to the PRDII DNA element from the interferon- $\beta$ promoter. Structure 10: 383-391.

Eto A, Muta T, Yamazaki S, Takeshige K. 2003. Essential roles for NF-кB and a Toll/IL-1 receptor domain-specific signal(s) in the induction of IкВל. Biochem Biophys Res Commun 301: 495-501.

Fiorini E, Schmitz I, Marissen WE, Osborn SL, Touma M, Sasada T, Reche PA, Tibaldi EV, Hussey RE, Kruisbeek AM, et al. 2002. Peptide-induced negative selection of thymocytes activates transcription of an NF- $\mathrm{kB}$ inhibitor. Mol Cell 9: 637-648.

Franzoso G, Bours V, Park S, Tomita-Yamaguchi M, Kelly K, Siebenlist U. 1992. The candidate oncoprotein Bcl-3 is an antagonist of p50/NF-kB-mediated inhibition. Nature 359: $339-342$.

Fusco AJ, Huang DB, Miller D, Wang VY, Vu D, Ghosh G. 2009. NF- $\mathrm{kB}$ p52:RelB heterodimer recognizes two classes of $\kappa \mathrm{B}$ sites with two distinct modes. EMBO Rep 10: $152-159$.

Ganchi PA, Sun SC, Greene WC, Ballard DW. 1993. A novel NF-кB complex containing p65 homodimers: Implications for transcriptional control at the level of subunit dimerization. Mol Cell Biol 13: 7826-7835.

Ge B, Li O, Wilder P, Rizzino A, McKeithan TW. 2003. NF- $\mathrm{B}$ regulates BCL3 transcription in T lymphocytes through an intronic enhancer. J Immunol 171: 4210-4218.

Ghosh S, Karin M. 2002. Missing pieces in the NF-кB puzzle. Cell 109 Suppl: S81-96.

Ghosh S, May MJ, Kopp EB. 1998. NF-кB AND REL PROTEINS: Evolutionarily Conserved Mediators of Immune Responses. Annu Rev Immunol 16: 225-260.

Ghosh G, van Duyne G, Ghosh S, Sigler PB. 1995. Structure of NF- $\mathrm{kB}$ p50 homodimer bound to a $\kappa \mathrm{B}$ site. Nature 373: $303-310$.

Groves MR, Barford D. 1999. Topological characteristics of helical repeat proteins. Curr Opin Struct Biol 9: 383-389.

Haruta H, Kato A, Todokoro K. 2001. Isolation of a novel interleukin-1-inducible nuclear protein bearing ankyrinrepeat motifs. J Biol Chem 276: 12485-12488.

Hatada EN, Nieters A, Wulczyn FG, Naumann M, Meyer R, Nucifora G, McKeithan TW, Scheidereit C. 1992. The ankyrin repeat domains of the NF-kB precursor p105 and the protooncogene bcl-3 act as specific inhibitors of NF- $\mathrm{KB}$ DNA binding. Proc Natl Acad Sci 89: 2489-2493. 
T. Huxford and G. Ghosh

Hayden MS, Ghosh S. 2008. Shared principles in NF-кB signaling. Cell 132: 344-362.

Herscovitch M, Comb W, Ennis T, Coleman K, Yong S, Armstead B, Kalaitzidis D, Chandani S, Gilmore TD. 2008. Intermolecular disulfide bond formation in the NEMO dimer requires Cys54 and Cys347. Biochem Biophys Res Commun 367: 103-108.

Hirotani T, Lee PY, Kuwata H, Yamamoto M, Matsumoto M, Kawase I, Akira S, Takeda K. 2005. The nuclear IкB protein IкBNS selectively inhibits lipopolysaccharideinduced IL-6 production in macrophages of the colonic lamina propria. J Immunol 174: 3650-3657.

Hoffmann A, Natoli G, Ghosh G. 2006. Transcriptional regulation via the NF-кB signaling module. Oncogene 25: 6706-6716.

Hoffmann A, Levchenko A, Scott ML, Baltimore D. 2002. The IкB-NF- $\mathrm{B}$ signaling module: Temporal control and selective gene activation. Science 298: 1241-1245.

Hu Y, Baud V, Oga T, Kim KI, Yoshida K, Karin M. 2001. IKK $\alpha$ controls formation of the epidermis independently of NF-кB Nature 410: 710-714.

Huang DB, Vu D, Ghosh G. 2005. NF-кB RelB forms an intertwined homodimer. Structure 13: 1365-1373.

Huang DB, Huxford T, Chen YQ, Ghosh G. 1997. The role of DNA in the mechanism of NF- $\mathrm{KB}$ dimer formation: Crystal structures of the dimerization domains of the p50 and p65 subunits. Structure 5: 1427-1436.

Huang TT, Kudo N, Yoshida M, Miyamoto S. 2000. A nuclear export signal in the $\mathrm{N}$-terminal regulatory domain of Iк $B \alpha$ controls cytoplasmic localization of inactive NF-кB/ІкB $\alpha$ complexes. Proc Natl Acad Sci 97: 1014-1019.

Huxford T, Malek S, Ghosh G. 2000. Preparation and crys-

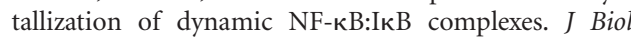
Chem 275: 32800-32806.

Huxford T, Huang DB, Malek S, Ghosh G. 1998. The crystal structure of the IкB $\alpha / N F-\kappa B$ complex reveals mechanisms of NF-кB inactivation. Cell 95: 759-770.

Ikeda F, Hecker CM, Rozenknop A, Nordmeier RD, Rogov V, Hofmann K, Akira S, Dotsch V, Dikic I. 2007. Involvement of the ubiquitin-like domain of TBK1/ IKK-i kinases in regulation of IFN-inducible genes. EMBO J 26: 3451-3462.

Jacobs MD, Harrison SC. 1998. Structure of an I $\mathrm{K} B \alpha /$ NF-кB complex. Cell 95: 749-758.

Jacque E, Tchenio T, Piton G, Romeo PH, Baud V. 2005. RelA repression of RelB activity induces selective gene activation downstream of TNF receptors. Proc Natl Acad Sci 102: 14635-14640.

Jaffray E, Wood KM, Hay RT. 1995. Domain organization of IкB $\alpha$ and sites of interaction with NF- $\mathrm{KB}$ p65. Mol Cell Biol 15: 2166-2172.

Johnson C, Van Antwerp D, Hope TJ. 1999. An N-terminal nuclear export signal is required for the nucleocytoplasmic shuttling of IкB $\alpha . E M B O J$ 18: 6682-6693.

Kearns JD, Basak S, Werner SL, Huang CS, Hoffmann A.

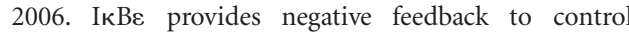
NF- $\mathrm{KB}$ oscillations, signaling dynamics, and inflammatory gene expression. J Cell Biol 173: 659-664.
Kitamura H, Kanehira K, Okita K, Morimatsu M, Saito M. 2000. MAIL, a novel nuclear IкB protein that potentiates LPS-induced IL-6 production. FEBS Lett 485: 53-56.

Lawrence T, Bebien M, Liu GY, Nizet V, Karin M. 2005. IKKa limits macrophage NF- $\mathrm{KB}$ activation and contributes to the resolution of inflammation. Nature 434: 1138-1143.

Li Z, Nabel GJ. 1997. A new member of the ІкB protein

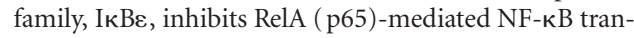
scription. Mol Cell Biol 17: 6184-6190.

Li Z-W, Chu W, Hu Y, Delhase M, Deerinck T, Ellisman M, Johnson R, Karin M. 1999c. The IKK $\beta$ subunit of IкB Kinase (IKK) is essential for nuclear factor $\kappa B$ activation and prevention of apoptosis. J Exp Med 189: 1839-1845.

Li Y, Kang J, Friedman J, Tarassishin L, Ye J, Kovalenko A, Wallach D, Horwitz MS. 1999b. Identification of a cell protein (FIP-3) as a modulator of NF- $\mathrm{kB}$ activity and as a target of an adenovirus inhibitor of tumor necrosis factor $\alpha$-induced apoptosis. Proc Natl Acad Sci 96: 1042-1047.

Li Q, Van Antwerp D, Mercurio F, Lee KF, Verma IM. 1999a. Severe liver degeneration in mice lacking the ІкВ kinase 2 gene. Science 284: 321-325.

Lo YC, Lin SC, Rospigliosi CC, Conze DB, Wu CJ, Ashwell JD, Eliezer D, Wu H. 2009. Structural basis for recognition of diubiquitins by NEMO Mol Cell 33: 602-615.

Makris C, Godfrey VL, Krahn-Senftleben G, Takahashi T, Roberts JL, Schwarz T, Feng L, Johnson RS, Karin M. 2000. Female mice heterozygous for IKK $\gamma / \mathrm{NEMO}$ deficiencies develop a dermatopathy similar to the human X-linked disorder incontinentia pigmenti. Mol Cell 5: 969-979.

Malek S, Chen Y, Huxford T, Ghosh G. 2001. ІкB $\beta$, but not I $B \alpha$, functions as a classical cytoplasmic inhibitor of NF- $\kappa \mathrm{B}$ dimers by masking both NF- $\mathrm{B}$ nuclear localization sequences in resting cells. J Biol Chem 276: $45225-45235$.

Malek S, Huang DB, Huxford T, Ghosh S, Ghosh G. 2003. $\mathrm{X}$-ray crystal structure of an IкB $\beta$ :NF- $\kappa B$ p 65 homodimer complex. J Biol Chem 278: 23094-23100.

Manning G, Whyte DB, Martinez R, Hunter T, Sudarsanam S. 2002. The protein kinase complement of the human genome. Science 298: 1912-1934.

Marienfeld RB, Palkowitsch L, Ghosh S. 2006. Dimerization of the IкB kinase-binding domain of NEMO is required for tumor necrosis factor $\alpha$-induced NF-kB activity. Mol Cell Biol 26: 9209-9219.

Marienfeld R, Berberich-Siebelt F, Berberich I, Denk A, Serfling E, Neumann M. 2001. Signal-specific and phosphorylation-dependent RelB degradation: A potential mechanism of NF- $\mathrm{KB}$ control. Oncogene 20: 8142-8147.

Marienfeld R, May MJ, Berberich I, Serfling E, Ghosh S, Neumann M. 2003. RelB forms transcriptionally inactive complexes with RelA/p65. J Biol Chem 278: 19852-19860.

Mathes E, O’Dea EL, Hoffmann A, Ghosh G. 2008. NF-кB dictates the degradation pathway of IкB $\alpha . E M B O J$ 27: 1357-1367.

May MJ, Marienfeld RB, Ghosh S. 2002. Characterization of the IкB-kinase NEMO binding domain. J Biol Chem 277: 45992-46000. 
May MJ, D’Acquisto F, Madge LA, Glockner J, Pober JS, Ghosh S. 2000. Selective inhibition of NF-кB activation by a peptide that blocks the interaction of NEMO with the IкB kinase complex. Science 289: 1550-1554.

Mercurio F, Murray BW, Shevchenko A, Bennett BL, Young DB, Li JW, Pascual G, Motiwala A, Zhu H, Mann M, et al. 1999. IкB kinase (IKK)-associated protein 1, a common component of the heterogeneous IKK complex. Mol Cell Biol 19: 1526-1538.

Mercurio F, Zhu H, Murray BW, Shevchenko A, Bennett BL, Li J, Young DB, Barbosa M, Mann M, Manning A, et al. 1997. IKK-1 and IKK-2: Cytokine-activated IкB kinases essential for NF-кB activation. Science 278: 860-866.

Michel F, Soler-Lopez M, Petosa C, Cramer P, Siebenlist U, Müller CW. 2001. Crystal structure of the ankyrin repeat domain of Bcl-3: A unique member of the ІкB protein family. EMBO J 20: 6180-6190.

Moorthy AK, Huang DB, Wang VY, Vu D, Ghosh G. 2007 $\mathrm{X}$-ray structure of a NF- $\mathrm{B}$ p50/RelB/DNA complex reveals assembly of multiple dimers on tandem $\mathrm{\kappa B}$ sites. J Mol Biol 373: 723-734.

Motoyama M, Yamazaki S, Eto-Kimura A, Takeshige K, Muta T. 2005. Positive and negative regulation of nuclear factor-кB-mediated transcription by ІкВ $\zeta$, an inducible nuclear protein. J Biol Chem 280: 7444-7451.

Müller CW, Rey FA, Harrison SC. 1996. Comparison of two different DNA-binding modes of the NF- $\mathrm{KB}$ p50 homodimer. Nat Struct Biol 3: 224-227.

Müller CW, Rey FA, Sodeoka M, Verdine GL, Harrison SC. 1995. Structure of the NF-кB p50 homodimer bound to DNA Nature 373: 311-317.

Mura C, McCammon JA. 2008. Molecular dynamics of a $\kappa$ B DNA element: Base flipping via cross-strand intercalative stacking in a microsecond-scale simulation. Nucleic Acids Res 36: 4941-4955.

Muta T, Yamazaki S, Eto A, Motoyama M, Takeshige K. 2003. ІкB $\zeta$, a new anti-inflammatory nuclear protein induced by lipopolysaccharide, is a negative regulator for nuclear factor-кB J Endotoxin Res 9: 187-191.

O’Dea EL, Barken D, Peralta RQ, Tran KT, Werner SL, Kearns JD, Levchenko A, Hoffmann A. 2007. A homeostatic model of IкB metabolism to control constitutive NF-кB activity. Mol Syst Bio 3: 111.

Ohno H, Takimoto G, McKeithan TW. 1990. The candidate proto-oncogene bcl-3 is related to genes implicated in cell lineage determination and cell cycle control. Cell 60: 991-997.

Pando MP, Verma IM. 2000. Signal-dependent and -independent Degradation of Free and NF- $\kappa B-b o u n d$ IкB $\alpha$ J Biol Chem 275: 21278-21286.

Panne D, Maniatis T, Harrison SC. 2007. An atomic model of the interferon- $\beta$ enhanceosome. Cell 129: $1111-1123$.

Peters RT, Maniatis T. 2001. A new family of IKK-related kinases may function as IкB kinase kinases. Biochim Biophys Acta 1471: M57-62.

Rahighi S, Ikeda F, Kawasaki M, Akutsu M, Suzuki N, Kato $\mathrm{R}$, Kensche T, Uejima T, Bloor S, Komander D, et al 2009. Specific recognition of linear ubiquitin chains by NEMO is important for NF-KB activation. Cell 136: 1098-1109.
Regnier CH, Song HY, Gao X, Goeddel DV, Cao Z, Rothe M. 1997. Identification and characterization of an IкB kinase. Cell 90: 373-383.

Riemann M, Endres R, Liptay S, Pfeffer K, Schmid RM. 2005. The IкB protein Bcl-3 negatively regulates transcription of the IL-10 gene in macrophages. J Immunol 175: $3560-3568$

Rogers S, Wells R, Rechsteiner M. 1986. Amino acid sequences common to rapidly degraded proteins: The PEST hypothesis. Science 234: 364-368.

Rothwarf DM, Zandi E, Natoli G, Karin M. 1998. IKK $\gamma$ is an essential regulatory subunit of the ІкB kinase complex. Nature 395: 297-300.

Rudolph D, Yeh WC, Wakeham A, Rudolph B, Nallainathan D, Potter J, Elia AJ, Mak TW. 2000. Severe liver degeneration and lack of NF-кB activation in NEMO/ IKK $\gamma$-deficient mice. Genes Dev 14: 854-862.

Rushe M, Silvian L, Bixler S, Chen LL, Cheung A, Bowes S, Cuervo H, Berkowitz S, Zheng T, Guckian K, et al. 2008. Structure of a NEMO/IKK-associating domain reveals architecture of the interaction site. Structure 16: $798-808$.

Savinova OV, Hoffmann A, Ghosh G. 2009. The NFKB1 and NFKB2 proteins p105 and p100 function as the core of high molecular-weight heterogenous complexes. Mol Cell 12: 591-602.

Schmidt-Supprian M, Bloch W, Courtois G, Addicks K, Isräel A, Rajewsky K, Pasparakis M. 2000. NEMO/ IKK $\gamma$-deficient mice model incontinentia pigmenti. Mol Cell 5: 981-992.

Sedgwick SG, Smerdon SJ. 1999. The ankyrin repeat: A diversity of interactions on a common structural framework. Trends Biochem Sci 24: 311-316.

Sen R, Baltimore D. 1986. Multiple nuclear factors interact with the immunoglobulin enhancer sequences. Cell 46: 705-716.

Senftleben U, Cao Y, Xiao G, Greten FR, Krahn G, Bonizzi G, Chen Y, Hu Y, Fong A, Sun SC, et al. 2001. Activation by IKK $\alpha$ of a second, evolutionary conserved, NF-кB signaling pathway. Science 293: 1495-1499.

Shaul JD, Farina A, Huxford T. 2008. The human IKK $\beta$ subunit kinase domain displays CK2-like phosphorylation specificity. Biochem Biophys Res Commun 374: 592-597.

Shih VF, Kearns JD, Basak S, Savinova OV, Ghosh G, Hoffmann A. 2009. Kinetic control of negative feedback regulators of NF-кB/RelA determines their pathogenand cytokine-receptor signaling specificity. Proc Natl Acad Sci 106: 9619-9624.

Sil AK, Maeda S, Sano Y, Roop DR, Karin M. 2004. IкB kinase- $\alpha$ acts in the epidermis to control skeletal and craniofacial morphogenesis. Nature 428: 660-664.

Simeonidis S, Liang S, Chen G, Thanos D. 1997. Cloning and functional characterization of mouse ІкB $\varepsilon$. Proc Natl Acad Sci 94: 14372-14377.

Sue SC, Cervantes C, Komives EA, Dyson HJ. 2008. Transfer of flexibility between ankyrin repeats in ІкB $\alpha$ upon formation of the NF-кB complex. J Mol Biol 380: 917-931.

Tam WF, Sen R. 2001. IкB family members function by different mechanisms. J Biol Chem 276: 7701-7704. 


\section{T. Huxford and G. Ghosh}

Tanaka M, Fuentes ME, Yamaguchi K, Durnin MH Dalrymple SA, Hardy KL, Goeddel DV. 1999. Embryonic lethality, liver degeneration, and impaired NF- $\kappa \mathrm{B}$ activation in IKK $\beta$-deficient mice. Immunity 10: 421-429.

Tegethoff S, Behlke J, Scheidereit C. 2003. Tetrameric oligomerization of IкB kinase $\gamma(\mathrm{IKK} \gamma)$ is obligatory for IKK complex activity and NF- $\mathrm{\kappa B}$ activation. Mol Cell Biol 23: 2029-2041.

Thompson JE, Phillips RJ, Erdjument-Bromage H, Tempst P, Ghosh S. 1995. IкB $\beta$ regulates the persistent response in a biphasic activation of NF-кB Cell 80: 573-582.

Tojima Y, Fujimoto A, Delhase M, Chen Y, Hatakeyama S, Nakayama K, Kaneko Y, Nimura Y, Motoyama N, Ikeda $\mathrm{K}$, et al. 2000. NAK is an IкB kinase-activating kinase. Nature 404: 778-782.

Trinh DV, Zhu N, Farhang G, Kim BJ, Huxford T. 2008. The nuclear I $\kappa$ B protein I $\mathrm{B} \zeta$ specifically binds NF- $\kappa$ B p50 homodimers and forms a ternary complex on $\kappa \mathrm{B}$ DNA J Mol Biol 379: 122-135.

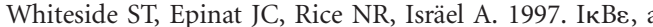
novel member of the IкB family, controls RelA and cRel NF- $\kappa$ B activity. EMBO J 16: 1413-1426.

Woronicz JD, Gao X, Cao Z, Rothe M, Goeddel DV. 1997. IкB kinase- $\beta$ : NF- $\kappa \mathrm{B}$ activation and complex formation with IкB kinase-a and NIK Science 278: 866-869.
Yamamoto M, Yamazaki S, Uematsu S, Sato S, Hemmi H, Hoshino K, Kaisho T, Kuwata H, Takeuchi O, Takeshige K, et al. 2004. Regulation of Toll/IL-1-receptor-mediated gene expression by the inducible nuclear protein ІкВ $\zeta$. Nature 430: 218-222.

Yamamoto Y, Verma UN, Prajapati S, Kwak YT, Gaynor RB. 2003. Histone H3 phosphorylation by IKK $\alpha$ is critical for cytokine-induced gene expression. Nature 423: 655-9.

Yamaoka S, Courtois G, Bessia C, Whiteside ST, Weil R, Agou F, Kirk HE, Kay RJ, Isräel A. 1998. Complementation cloning of NEMO, a component of the IкB kinase complex essential for NF-кB activation. Cell 93: $1231-1240$.

Yamazaki S, Muta T, Takeshige K. 2001. A novel IкB protein, IкB- $\zeta$, induced by proinflammatory stimuli, negatively regulates nuclear factor- $\mathrm{\kappa B}$ in the nuclei. $\mathrm{J} \mathrm{Biol} \mathrm{Chem}$ 276: $27657-27662$.

Zandi E, Rothwarf DM, Delhase M, Hayakawa M, Karin M. 1997. The ІкB kinase complex (IKK) contains two kinase subunits, IKK $\alpha$ and IKK $\beta$, necessary for ІкB phosphorylation and NF- $\mathrm{B}$ activation. Cell 91: 243-252.

Zandi E, Chen Y, Karin M. 1998. Direct phosphorylation of IкB by IKK $\alpha$ and IKK $\beta$ : Discrimination between free and NF-кB-bound substrate. Science 281: 1360-1363. 


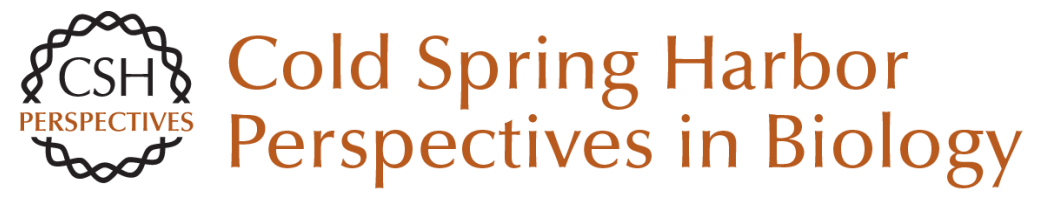

\section{A Structural Guide to Proteins of the NF-kB Signaling Module}

Tom Huxford and Gourisankar Ghosh

Cold Spring Harb Perspect Biol 2009; doi: 10.1101/cshperspect.a000075

Subject Collection NF-kB

Use of Forward Genetics to Discover Novel

Regulators of NF- $\mathrm{KB}$

Tao Lu and George R. Stark

Selectivity of the NF- $\kappa B$ Response

Ranjan Sen and Stephen T. Smale

NF- $\kappa B$ in the Nervous System

Barbara Kaltschmidt and Christian Kaltschmidt

Signaling to NF-кB: Regulation by Ubiquitination Ingrid E. Wertz and Vishva M. Dixit

Ubiquitination and Degradation of the Inhibitors of NF- $\kappa B$

Naama Kanarek, Nir London, Ora

Schueler-Furman, et al.

A Structural Guide to Proteins of the NF- $\kappa B$

Signaling Module

Tom Huxford and Gourisankar Ghosh

NF- $\mathrm{KB}$ in the Immune Response of Drosophila

Charles Hetru and Jules A. Hoffmann

Control of NF-kB-dependent Transcriptional

Responses by Chromatin Organization

Gioacchino Natoli
Oncogenic Activation of NF-KB

Louis M. Staudt

The Regulatory Logic of the NF- $\kappa B$ Signaling

System

Ellen O'Dea and Alexander Hoffmann

Roles of the NF-kB Pathway in Lymphocyte

Development and Function

Steve Gerondakis and Ulrich Siebenlist

The IKK Complex, a Central Regulator of NF- $\kappa B$

Activation

Alain Israël

NF- $\kappa B$ in the Nervous System

Barbara Kaltschmidt and Christian Kaltschmidt

The Nuclear Factor NF- $\kappa B$ Pathway in Inflammation

Toby Lawrence

NF- $\kappa B$ as a Critical Link Between Inflammation and Cancer

Michael Karin

Specification of DNA Binding Activity of NF-KB

Proteins

Fengyi Wan and Michael J. Lenardo

For additional articles in this collection, see http://cshperspectives.cshlp.org/cgi/collection/

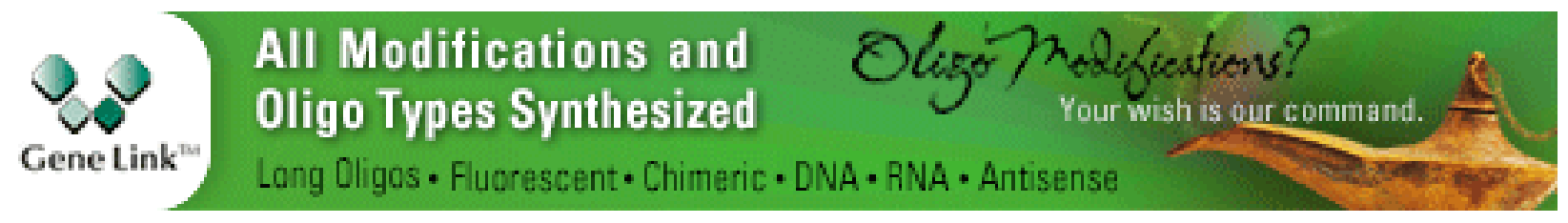

Copyright (C) 2009 Cold Spring Harbor Laboratory Press; all rights reserved 